\title{
PERBANDINGAN HASIL PERHITUNGAN PREMI ASURANSI JIWA ENDOWMENT SUKU BUNGA VASICEK DENGAN DAN TANPA SIMULASI MONTE CARLO
}

\author{
Desi Kurnia Sari ${ }^{1 \S}$, I Nyoman Widana ${ }^{2 \S}$, Kartika Sari ${ }^{3}$ \\ ${ }^{1}$ Jurusan Matematika, Fakultas MIPA - Universitas Udayana [Email: desikur.dk@ gmail.com] \\ ${ }^{2}$ Jurusan Matematika, Fakultas MIPA - Universitas Udayana [Email:nwidana@yahoo.com] \\ ${ }^{3}$ Jurusan Matematika, Fakultas MIPA - Universitas Udayana [Email: sari_kaartika@yahoo.co.id] \\ ${ }^{\S}$ Corresponding Author
}

\begin{abstract}
Vasicek is one of the stochastic interest rate model that can capture interest rates movement. The aim of this research was to get the comparison of the level premium for an endowment life insurance under stochastic interest rate without and by using Monte Carlo simulation. The result show that the level premium without Monte Carlo simulation is not much different from the result of the level premium by using Monte Carlo simulation. However, the premium calculation by using Monte Carlo simulation can also be searched the range of losses and gains of the insurance company at certain confidence interval. In this case using a confidence interval of $95 \%$.
\end{abstract}

Keywords: Premium calculation, Endowment life insurance, Vasicek, Monte Carlo simulation

\section{PENDAHULUAN}

Asuransi jiwa endowment adalah salah satu jenis asuransi jiwa yang memberikan nilai tunai manfaat kepada pihak tertanggung sekaligus investasi. Setiap orang yang mengikuti asuransi wajib membayar premi. Premi merupakan sejumlah uang yang wajib dibayarkan pihak tertanggung kepada pihak penanggung sesuai dengan kontrak asuransi yang telah disepakati. Terdapat beberapa faktor yang harus diperhatikan dalam perhitungan premi asuransi jiwa, yaitu: biaya perusahaan, tingkat kematian dan tingkat suku bunga (Sembiring, 1986).

Sehubungan dengan tingkat suku bunga, selama ini perhitungan premi dilakukan dengan menggunakan suku bunga tetap, sedangkan berdasarkan kenyataan yang ada suku bunga selalu berubah-ubah secara tidak menentu karena berbagai faktor yang memengaruhinya. Vasicek merupakan salah satu model suku bunga stokastik yang dapat menangkap perubahaan suku bunga tersebut (Zetyun, 2007).

Soffan (2011) telah melakukan perhitungan premi asuransi jiwa berjangka menggunakan suku bunga Vasicek. Hasil penelitiannya adalah besar nilai suku bunga awal yang digunakan dalam perhitungan premi tidak memengaruhi konvergensi nilai suku bunga menuju tingkat suku bunga rata-rata. Sementara itu, sejauh ini penelitian mengenai perhitungan premi asuransi jiwa endowment suku bunga Vasicek menggunakan simulasi Monte Carlo belum pernah dilakukan. Simulasi Monte Carlo merupakan suatu metode simulasi yang dilakukan dengan cara membangkitkan bilangan acak. Menurut Dickson et al (2013), kelebihan metode simulasi Monte Carlo dalam perhitungan premi asuransi adalah dapat dicari kisaran kerugian dan keuntungan yang dialami perusahaan asuransi dengan tingkat kepercayaan tertentu.

Berdasarkan permasalahan yang telah diuraikan, dalam penelitian ini dikaji perhitungan premi asuransi jiwa endowment suku bunga Vasicek dengan simulasi Monte Carlo. Selanjutnya dibahas perbandingan hasil perhitungan premi asuransi jiwa endowment suku bunga Vasicek dengan dan tanpa menggunakan simulasi Monte Carlo. 
Dengan demikian tujuan dari penelitian adalah:

1. Untuk mengetahui hasil perhitungan premi asuransi jiwa endowment suku bunga Vasicek dengan simulasi Monte Carlo.

2. Untuk mengetahui perbandingan hasil perhitungan premi asuransi jiwa endowment suku bunga Vasicek dengan dan tanpa simulasi Monte Carlo.

Selanjutnya dibahas konsep-konsep yang digunakan untuk menentukan premi asuransi jiwa endowment suku bunga Vasicek dengan dan tanpa simulasi Monte Carlo.

Peluang seseorang berusia $x$ tahun akan tetap hidup hingga mencapai usia $x+t$ tahun dinotasikan dengan ${ }_{t} p_{x}$ dan peluang seseorang berusia $x$ tahun akan meninggal sebelum usia $x+t$ tahun dinotasikan dengan ${ }_{t} q_{x}$ yang secara berturut-turut didefinisikan (Bowers et al, 1997) sebagai:

$$
\begin{aligned}
& { }_{t} p_{x}=P\left[T_{x}>t\right], t \geq 0 \\
& { }_{t} q_{x}=P\left[T_{x} \leq t\right]=1-{ }_{t} p_{x} t \geq 0
\end{aligned}
$$

Distribusi Gompertz merupakan salah satu distribusi yang sering digunakan dalam menggambarkan usia kematian seseorang. Fungsi peluang ${ }_{t} p_{x}$ dan ${ }_{t} q_{x}$ menurut fungsi distribusi Gompertz (Dickson et al, 2011) adalah:

$$
\begin{aligned}
& { }_{t} p_{x}=\exp \left[-\frac{B c^{x}}{\ln c}\left(c^{t}-1\right)\right] \\
& { }_{t} q_{x}=1-\exp \left[-\frac{B c^{x}}{\ln c}\left(c^{t}-1\right)\right]
\end{aligned}
$$

Jumlah seseorang berusia $x+t+1$ tahun apabila diketahui jumlah seseorang berusia $x+t$ tahun dan peluang seseorang berusia $x+t$ tahun akan tetap hidup hingga mencapai usia $x+t+1$ tahun (Futami, 1993) adalah:

$$
\begin{aligned}
& l_{x+t+1}=l_{x+t} \cdot p_{x+t} \\
&=l_{x} \cdot t+1 \\
& p_{x}
\end{aligned}
$$

Lebih lanjut lagi, peluang seseorang berusia $x+t$ tahun akan meninggal sebelum usia $x+t+1$ tahun dinotasikan dengan $q_{x+t}$ dan dirumuskan (Futami, 1993) sebagai:

$$
q_{x+t}=1-\frac{l_{x+t+1}}{l_{x+t}}
$$

Asuransi jiwa endowment merupakan perpaduan antara asuransi jiwa berjangka dan asuransi jiwa dwiguna murni. Apabila tertanggung meninggal selama jangka waktu kontrak misalkan $t$ tahun, maka pada pewarisnya akan dibayarkan uang pertanggungan, namun apabila tertanggung dapat mencapai usia $x+t$ tahun, maka kepadanya akan dibayarkan uang pertanggungan pada akhir tahun $x+t$ (Sembiring, 1986).

Nilai tunai manfaat merupakan sejumlah uang yang diterima pihak tertanggung pada saat melakukan klaim. Actuarial Present Value untuk manfaat asuransi jiwa endowment dinotasikan dengan $A_{x: \bar{n}\rceil}$ dan didefinisikan (Bowers et al, 1997) sebagai:

$$
A_{\overline{x: n\rceil}}=\sum_{k=0}^{n-1} v^{k+1}{ }_{k} p_{x} q_{x+k}+v^{n}{ }_{n x}
$$

Anuitas adalah suatu pembayaran dalam jumlah tertentu yang dilakukan setiap selang waktu dan jangka waktu tertentu, secara berkelanjutan (Futami, 1993). Actuarial Present Value dari anuitas asuransi jiwa endowment dinotasikan dengan $\ddot{a}_{x: \bar{\eta}}$ dan didefinisikan (Dickson et al, 2013) sebagai:

$$
\ddot{a}_{x: \bar{n}\rceil}=\sum_{k=0}^{n-1} v_{k}^{k} p_{x}
$$

Dalam perhitungan premi asuransi, premi dibayarkan oleh pihak tertanggung sehingga ekspektasi nilai tunai dari kerugian finansial yang diderita oleh pihak penanggung pada saat polis dikeluarkan sama dengan nol. Untuk merumuskan prinsip tersebut, besar kerugian pihak penanggung dinotasikan dengan $L$ yang merupakan variabel acak dari nilai tunai manfaat yang dibayarkan oleh pihak penanggung dikurangi variabel acak nilai tunai anuitas dari premi yang dibayarkan oleh pihak tertanggung. Prinsip tersebut disebut prinsip ekuivalensi dan dapat ditulis (Dickson et al, 2013) sebagai:

$$
E(L)=0
$$

Untuk asuransi jiwa endowment n-tahun dengan nilai manfaat sebesar 1 rupiah, nilai $L=1 . v^{\min (K+1, n)}-P . \ddot{a}_{\min (K+1, n)}$. Dengan mensubstitusi nilai $L$ ke persamaan (9) diperoleh

$$
\begin{aligned}
& E\left(1 . v^{\min (K+1, n)}-P . \ddot{a}_{\min (K+1, n)}\right)=0 \\
& E\left(1 . v^{\min (K+1, n)}\right)=P \cdot \ddot{a}_{\min (K+1, n)}
\end{aligned}
$$




$$
\begin{aligned}
& A_{\overline{x: n]}}=P \ddot{a}_{x \bar{n} \overline{1}} \\
& P=\frac{A_{\overline{x: n]}}}{\ddot{a}_{x: n\rceil}}
\end{aligned}
$$

Selanjutnya, premi tahunan asuransi jiwa endowment dapat diperoleh dengan mensubstitusikan persamaan (7) dan (8) ke persamaan (10) yaitu:

$$
P=\frac{\sum_{k=0}^{n-1} v^{k+1}{ }_{k} p_{x} q_{x+k}+v^{n}{ }_{n} p_{x}}{\sum_{k=0}^{n-1} v^{k}{ }_{k} p_{x}}
$$

Suku bunga model Vasicek merupakan suatu model suku bunga stokastik yang mempunyai ciri khusus yaitu tingkat suku bunga akan cenderung kembali ke tingkat suku bunga ratarata setelah mengalami penurunan atau peningkatan dan selanjutnya didefinisikan (Zetun dan Gupta, 2007) sebagai:

$$
d r(t)=\kappa[\theta-r(t)] d t+\sigma d W(t)
$$

dengan $r, \kappa$ dan $\theta$ merupakan suatu konstanta positif.

Ekspektasi nilai tunai pembayaran sebesar satu unit pada saat $k$ dengan tingkat suku bunga mengikuti model Vasicek dinotasikan dengan $P(k)$ dan didefinisikan (Zetun dan Gupta, 2007) sebagai:

$$
\begin{array}{r}
P(k)=\exp \left\{\left(\theta-\frac{\sigma^{2}}{2 \kappa^{2}}\right)(B(k)-k)-\right. \\
\left.\frac{\sigma^{2}}{4 \kappa} B(k)^{2}-r(0) B(k)\right\}
\end{array}
$$

dengan $B(k)=\frac{1-e^{-k \kappa}}{\kappa}$.

Berdasarkan persamaan (7) dan (13), nilai manfaat asuransi jiwa endowment suku bunga Vasicek dapat dinyatakan sebagai:

$$
\begin{aligned}
A_{\overline{x: n]}}= & \sum_{k=0}^{n-1} P(k+1)_{k} p_{x} q_{x+k}+ \\
& P(n){ }_{n} p_{x}
\end{aligned}
$$

Nilai tunai anuitas asuransi jiwa endowment suku bunga Vasicek dapat diperoleh berdasarkan persamaan (8) dan (13) yaitu:

$$
\ddot{a}_{x: \bar{n}\rceil}=\sum_{k=0}^{n-1} P(k){ }_{k} p_{x}
$$

Dengan mensubstitusi persamaan (14) dan (15) ke persamaan (10) diperoleh nilai premi asuransi jiwa endowment suku bunga Vasicek sebagai:

$$
P=\frac{\sum_{k=0}^{n-1} P(k+1){ }_{k} p_{x} q_{x+k}+P(n){ }_{n} p_{x}}{\sum_{k=0}^{n-1} P(k){ }_{k} p_{x}}
$$

Simulasi Monte Carlo adalah suatu metode simulasi untuk mengevaluasi suatu model deterministik yang melibatkan bilangan acak sebagai salah satu input. Salah satu metode yang digunakan dalam simulasi Monte Carlo adalah metode transformasi invers. Metode ini memudahkan kita untuk membuat simulasi amatan dari suatu variabel acak $T$ ketika kita menggunakan pembangkit bilangan acak yang berdistribusi seragam $U(0,1)$.

Metode transformasi invers menyatakan jika $F(t)=P(T \leq t)$ dan $u$ adalah suatu bilangan acak yang diambil dari $U(0,1)$, maka (Dickson et al, 2013):

$$
\begin{aligned}
t & =F^{-1}(u) \\
& =\frac{1}{\log c}\left(\log \left(1-\frac{\log (c) \log (1-u)}{B c^{x}}\right)\right)
\end{aligned}
$$

Kelebihan metode simulasi Monte Carlo dalam perhitungan premi asuransi adalah dapat dicari kisaran kerugian dan keuntungan perusahaan asuransi dengan tingkat kepercayaan tertentu. Nilai kerugian atau keuntungan yang dialami perusahaan asuransi dinotasikan dengan $L_{O}$ dan dinyatakan sebagai:

$$
L_{O}=A_{M C}-P_{M C} \cdot \ddot{a}_{M C}
$$

dengan $A_{M C}$ merupakan nilai tunai manfaat dan $\ddot{a}_{M C}$ nilai tunai anuitas asuransi jiwa endowment suku bunga Vasicek menggunakan simulasi Monte Carlo.

Selanjutnya misalkan $\bar{l}$ dan $s l$ secara berturut-turut adalah nilai harapan dan standar deviasi dari nilai kerugian atau keuntungan premi yang dialami oleh perusahaan asuransi, maka kisaran kerugian atau keuntungan yang dialami oleh perusahaan asuransi untuk tingkat kepercayaan 95\% dapat dinyatakan (Dickson et $a l, 2013)$ sebagai berikut :

$$
\left(\bar{l}-1.96 \frac{s l}{\sqrt{n}}, \bar{l}+1.96 \frac{s l}{\sqrt{n}}\right)
$$

dengan $n$ merupakan jumlah bilangan acak yang dibangkitkan. 


\section{METODE PENELITIAN}

Penelitian ini menggunakan data sekunder, yaitu data yang terdapat dalam Tabel Mortalita Indonesia 2011. Pengolahan data pada penelitian ini menggunakan alat bantu Software Microsoft Excell dan R i386 3.8.0.

Adapun tahap-tahap analisis data yang digunakan dalam penelitian ini adalah sebagai berikut:

1. Estimasi parameter distribusi Gompertz.

2. Estimasi parameter suku bunga Vasicek menggunakan metode Maximum Likelihood Estimator (MLE) dengan bantuan Software R i386 3.2.0.

3. Melakukan simulasi perhitungan premi untuk peserta asuransi usia $30,35,40,45,50,55$ dan 60 tahun tanpa simulasi Monte Carlo dengan langkah-langkah: (a)Menentukan nilai ${ }_{k} p_{x}, \quad l_{x+k+1}$ dan $q_{x+k}$ menggunakan distribusi Gompertz; (b)Menghitung nilai tunai manfaat asuransi jiwa endowment suku bunga Vasicek; (c)Menghitung nilai tunai anuitas asuransi jiwa endowment suku bunga Vasicek; (d)Menghitung nilai premi asuransi jiwa endowment suku bunga Vasicek.

4. Melakukan simulasi perhitungan premi untuk peserta asuransi usia 30, 35, 40, 45, 50, 55 dan 60 tahun menggunakan simulasi Monte Carlo dengan langkah-langkah sebagai berikut: (a)Membangkitkan bilangan acak dengan distribusi $U(0,1)$; (b)Menghitung sisa usia pihak tertanggung $(t)$; (c)Menghitung floor dari sisa usia pihak tertanggung $(t)$ yang diperoleh pada langkah (5.b); (d)Menghitung nilai tunai manfaat asuransi jiwa endowment suku bunga Vasicek; (e)Menghitung nilai tunai anuitas asuransi jiwa endowment suku bunga Vasicek; (f)Menghitung nilai premi asuransi jiwa endowment suku bunga Vasicek; (g)Menghitung kisaran kerugian dan keuntungan perusahaan asuransi dengan tingkat kepercayaan 95\%; (h)Membandingkan hasil perhitungan premi asuransi jiwa endowment suku bunga Vasicek tanpa simulasi Monte Carlo pada langkah (3.d) dan dengan simulasi Monte Carlo pada langkah (4.f).

\section{HASIL DAN PEMBAHASAN}

Berdasarkan persamaan (4) yang merupakan peluang pihak tertanggung berusia $x$ tahun meninggal sebelum mencapai usia $x+t$ tahun menurut fungsi distribusi Gompertz, dihitung nilai $t=1$, sehingga diperoleh:

$$
q_{x}=1-\exp \left[-\frac{B c^{x}}{\ln c}(c-1)\right]
$$

Selanjutnya dengan menggunakan persamaan (20) dicari nilai parameter $B$ dan $C$ sebagai berikut:

$$
\begin{aligned}
1-q_{x} & =\exp \left[-\frac{B c^{x}}{\ln c}(c-1)\right] \\
\ln \left(1-q_{x}\right) & =-\frac{B c^{x}}{\ln c}(c-1) \\
\ln \left(\ln \frac{1}{\left(1-q_{x}\right)}\right) & =x \ln c+\ln \left(\frac{B(c-1)}{\ln c}\right)
\end{aligned}
$$

Apabila dimisalkan:

$$
\begin{aligned}
& y=\ln \left(\ln \frac{1}{\left(1-q_{x}\right)}\right) \\
& a=\ln c \\
& b=\ln \left(\frac{B(c-1)}{\ln c}\right)
\end{aligned}
$$

maka persamaan (21) dapat ditulis dalam bentuk persamaan linier sebagai:

$$
y=a x+b
$$

Berdasarkan persamaan (22), dengan menggunakan data $q_{x}$ yang terdapat dalam Tabel Mortalita Indonesia 2011 dan bantuan software Microsoft Excell diperoleh bentuk persamaan linier dari distribusi Gompertz yaitu $y=0.0962762 x-10.1474261$. Dari sini diperoleh nilai parameter $B=0.0000373$ dan $c=1.1010631$.

Dengan menggunakan nilai $B$ dan $c$ yang diperoleh, maka persamaan (4) dapat ditulis sebagai:

$$
\begin{array}{r}
{ }_{k} q_{x}=1-\exp \left[-\frac{0.0000373 \times(1.1010631)^{x}}{0.0962762} \times\right. \\
\left.\left(1.1010631^{k}-1\right]\right)
\end{array}
$$

Parameter dari suku bunga model Vasicek diestimasi menggunakan data observasi berupa data rata-rata tingkat suku bunga tahunan Bank Indonesia (BI Rate) dari bulan Desember 2005 sampai Desember 2015. Estimasi parameter 
dilakukan menggunakan metode Maximum Likelihood Estimator (MLE).

Dengan bantuan software $\mathrm{R}$ i386 3.2.0, diperoleh hasil estimasi parameter suku bunga model Vasicek yaitu: $k=0.4568226, \quad \theta=$ 0.0676134 dan $\sigma=0.0103116$.

Langkah selanjutnya adalah melakukan simulasi perhitungan premi. Simulasi perhitungan premi dilakukan untuk pihak tertanggung berusia 30, 35, 40, 45, 50, 55 dan 60 tahun. Simulasi dilakukan tanpa dan dengan menggunakan simulasi Monte Carlo. Pada penelitian ini dihitung untuk pembayaran premi yang dilakukan setiap tahun selama jangka waktu kontrak asuransi dan pihak tertanggung masih hidup. Jangka waktu kontrak asuransi yang digunakan adalah 30 tahun dengan uang pertanggungan sebesar Rp. 100.000.000,- dan suku bunga awal yang digunakan $\left(r_{0}\right)$ sebesar $12.75 \%$.

Nilai peluang ${ }_{k} p_{x}, l_{x+k+1}$ dan $q_{x+k}$ secara berturut-turut dapat ditentukan berdasarkan persamaan (23), (5) dan (6). Nilai-nilai peluang tersebut selanjutnya digunakan untuk menghitung nilai tunai manfaat, nilai tunai anuitas dan nilai premi asuransi jiwa endowment suku bunga Vasicek tanpa simulasi Monte Carlo.

Nilai tunai manfaat asuransi jiwa endowment suku bunga Vasicek tanpa simulasi Monte Carlo dapat ditentukan menggunakan persamaan (14). Nilai tunai manfaat dihitung berdasarkan nilai-nilai peluang distribusi Gompertz dan Tabel Mortalita Indonesia (TMI) 2011. Hasil perhitungan nilai tunai manfaat asuransi jiwa endowment suku bunga Vasicek tanpa menggunakan simulasi Monte Carlo dapat dilihat pada Tabel 1.

Tabel 1. Nilai Tunai Manfaat Tanpa Simulasi Monte Carlo

\begin{tabular}{|c|c|c|}
\hline Usia (tahun) & Gompertz & TMI 2011 \\
\hline 30 & 0.1295191 & 0.1299894 \\
\hline 35 & 0.1373989 & 0.1400765 \\
\hline 40 & 0.1497501 & 0.1540448 \\
\hline 45 & 0.1685982 & 0.1890444 \\
\hline 50 & 0.1964354 & 0.2398891 \\
\hline 55 & 0.2356408 & 0.3233357 \\
\hline 60 & 0.2874193 & 0.4619119 \\
\hline
\end{tabular}

Berdasarkan Tabel 1 dapat dilihat bahwa nilai tunai manfaat asuransi jiwa endowment suku bunga Vasicek yang dihitung menggunakan TMI 2011 menghasilkan nilai tunai manfaat yang lebih besar dibandingkan dengan hasil perhitungan menggunakan distribusi Gompertz.

Nilai tunai anuitas asuransi jiwa endowment suku bunga Vasicek dapat ditentukan menggunakan persamaan (15). Nilai tunai anuitas juga dihitung berdasarkan nilai-nilai peluang distribusi Gompertz dan TMI 2011. Hasil perhitungan nilai tunai anuitas asuransi jiwa endowment suku bunga Vasicek tanpa menggunakan simulasi Monte Carlo dapat dilihat pada Tabel 2.

Tabel 2. Nilai Tunai Anuitas Tanpa Simulasi Monte Carlo

\begin{tabular}{|c|c|c|}
\hline Usia (tahun) & Gompertz & TMI 2011 \\
\hline 30 & 11.7645501 & 11.9372685 \\
\hline 35 & 11.6440825 & 11.9173377 \\
\hline 40 & 11.4563014 & 11.8855804 \\
\hline 45 & 11.1698983 & 11.8369139 \\
\hline 50 & 10.7472794 & 11.7575423 \\
\hline 55 & 10.1529599 & 11.6362825 \\
\hline 60 & 9.3700304 & 11.4408083 \\
\hline
\end{tabular}

Tabel 2 menunjukkan bahwa hasil perhitungan nilai tunai anuitas asuransi jiwa endowment suku bunga Vasicek menggunakan distribusi Gompertz lebih besar dibandingkan dengan hasil perhitungan menggunakan TMI 2011.

Nilai premi asuransi jiwa endowment suku bunga Vasicek dapat ditentukan berdasarkan persamaan (10) dengan nilai tunai manfaat dan nilai tunai anuitas secara berturut-turut dapat dilihat pada Tabel 1 dan Tabel 2. Hasil perhitungan premi asuransi jiwa endowment suku bunga Vasicek tanpa simulasi Monte Carlo dengan uang pertanggungan sebesar Rp. 1,dapat dilihat pada Tabel 3.

Berdasarkan Tabel 3 dapat dilihat bahwa nilai premi asuransi jiwa endowment suku bunga Vasicek yang dihitung menggunakan distribusi Gompertz lebih mahal dibandingkan dengan nilai premi yang dihitung menggunakan TMI 2011. Dengan uang pertanggungan sebesar 
Rp. 100.000.000,- maka nilai premi yang harus dibayarkan pihak tertanggung berusia 35 tahun menggunakan distribusi Gompertz sebesar Rp. 1.179.980,- sedangkan dengan TMI 2011 sebesar Rp. 1.175.400,-.

Tabel 3. Premi Tanpa Simulasi Monte Carlo

\begin{tabular}{|c|c|c|}
\hline Usia (tahun) & Gompertz & TMI 2011 \\
\hline 30 & 0.1295191 & 0.1299894 \\
\hline 35 & 0.1373989 & 0.1400765 \\
\hline 40 & 0.1497501 & 0.1540448 \\
\hline 45 & 0.1685982 & 0.1890444 \\
\hline 50 & 0.1964354 & 0.2398891 \\
\hline 55 & 0.2356408 & 0.3233357 \\
\hline 60 & 0.2874193 & 0.4619119 \\
\hline
\end{tabular}

Setelah memperoleh nilai premi tanpa menggunakan simulasi Monte Carlo, langkah selanjutnya adalah melakukan simulasi perhitungan premi dengan simulasi Monte Carlo. Langkah pertama dalam melakukan perhitungan premi asuransi jiwa endowment suku bunga Vasicek menggunakan simulasi Monte Carlo adalah membangkitkan bilangan acak berdistribusi $U(0,1)$ sebanyak 5000 dengan bantuan software Microsoft Excell, namakan $u_{0}, u_{1}, u_{2}, \ldots, u_{4999}$. Selanjutnya menentukan sisa usia dari pihak tertanggung $(t)$.

Sisa usia pihak tertanggung $(t)$ dapat ditentukan berdasarkan persamaan (17) dengan nilai-nilai parameter distribusi Gompertz yaitu $B=0.0000373$ dan $c=1.1010631$, sehingga persamaan (17) dapat ditulis sebagai:

$t=F^{-1}(u)$

$=\frac{1}{\log 1.1010631}\left(\log \left(1-\frac{\log (1.1010631) \log (1-u)}{(0.0000373)(1.1010631)^{x}}\right)\right)$ dengan $u$ merupakan bilangan acak berdistribusi $U(0,1)$.

Nilai $t_{0}, t_{1}, t_{2}, \ldots, t_{4999}$ dihitung untuk pihak tertanggung berusia $30,35,40,45,50,55$ dan 60 tahun. Setelah diperoleh nilai $t_{0}, t_{1}, t_{2}, \ldots, t_{4999}$, langkah selanjutnya adalah mencari nilai floor dari $t_{0}, t_{1}, t_{2}, \ldots, t_{4999}$. Untuk memudahkan perhitungan, dimisalkan nilai $\left\lfloor t_{0}\right\rfloor,\left\lfloor t_{1}\right\rfloor,\left\lfloor t_{2}\right\rfloor, \ldots,\left\lfloor t_{4999}\right\rfloor=k_{0}, k_{1}, k_{2}, \ldots, k_{4999}$. Apabila nilai floor dari sisa usia pihak tertanggung yang diperoleh melebihi jangka waktu kontrak asuransi, maka digunakan nilai pada batas akhir kontrak asuransi tersebut.
Namun, apabila nilai floor dari sisa usia pihak tertanggung kurang atau sama dengan jangka waktu kontrak asuransi, maka digunakan nilai floor dari sisa usia pihak tertanggung itu sendiri.

Nilai dari $k_{0}, k_{1}, k_{2}, \ldots, k_{4999}$ yang diperoleh selanjutnya digunakan dalam perhitungan nilai tunai manfaat, nilai tunai anuitas dan nilai premi asuransi jiwa endowment suku bunga Vasicek menggunakan simulasi Monte Carlo yang secara berturut-turut dinotasikan dengan $A_{M C}, \ddot{a}_{M C}$ dan $P_{M C}$.

Nilai tunai manfaat asuransi jiwa endowment suku bunga Vasicek menggunakan simulasi Monte Carlo dihitung dengan simulasi sebanyak 5000 dan dirumuskan sebagai:

$$
\begin{gathered}
A_{M C}=\frac{1}{5000}\left[\sum_{n=0, k_{n} \leq 29}^{4999} P\left(k_{n}+1\right)+\right. \\
\left.\sum_{n=0, k_{n}>29}^{4999} P(29)\right]
\end{gathered}
$$

dengan

$P\left(k_{n}+1\right)=\exp \left\{\left(0.0676-\frac{(0.0103)^{2}}{2(0.4568)^{2}}\right)\left(B\left(k_{n}+\right.\right.\right.$
$\left.1)-\left(k_{n}+1\right)\right)-\frac{(0.0103)^{2}}{4(0.4568)} B\left(k_{n}+1\right)^{2}-$
$\left.r(0) B\left(k_{n}+1\right)\right\}$ dan $B\left(k_{n}+1\right)=\frac{1-\mathrm{e}^{-0.4568\left(k_{n}+1\right)}}{0.4568}$.

Berdasarkan persamaan (24), dihitung nilai tunai manfaat asuransi jiwa endowment suku bunga Vasicek dengan simulasi Monte Carlo untuk pihak tertanggung berusia 30, 35, 40, 45, 50, 55 dan 60 tahun.

Hasil perhitungan nilai tunai manfaat asuransi jiwa endowment suku bunga Vasicek dengan simulasi Monte Carlo dapat dilihat pada Tabel 4.

Tabel 4. Nilai Tunai Manfaat dengan Simulasi Monte Carlo.

\begin{tabular}{|c|c|}
\hline $\begin{array}{c}\text { Usia } \\
\text { (tahun) }\end{array}$ & Nilai Tunai Manfaat \\
\hline 30 & 0.1297435 \\
\hline 35 & 0.1375410 \\
\hline 40 & 0.1499880 \\
\hline 45 & 0.1688836 \\
\hline 50 & 0.1965845 \\
\hline 55 & 0.2359298 \\
\hline 60 & 0.2874297 \\
\hline
\end{tabular}

Berdasarkan Tabel 4 dapat dilihat bahwa semakin tinggi usia pihak tertanggung yang mengikuti asuransi, maka nilai tunai manfaat yang diperoleh akan semakin besar. 
Nilai tunai anuitas asuransi jiwa endowment suku bunga Vasicek menggunakan simulasi

$$
\begin{gathered}
\ddot{a}_{M C}=\frac{1}{5000}\left[\sum_{n=0, k_{n} \leq 29}^{4999} \sum_{n=0}^{k_{n}} P\left(k_{n}\right)+\right. \\
\left.\sum_{i=0, k_{n}>30}^{4999} \sum_{n=0,}^{29} P\left(k_{n}\right)\right]
\end{gathered}
$$

dengan

$$
\begin{aligned}
P\left(k_{n}\right)= & \exp \left\{( 0 . 0 6 7 6 - \frac { ( 0 . 0 1 0 3 ) ^ { 2 } } { 2 ( 0 . 4 5 6 8 ) ^ { 2 } } ) \left(B\left(k_{n}\right)-\right.\right. \\
& \left.\left.k_{n}\right)-\frac{(0.0103)^{2}}{4(0.4568)} B\left(k_{n}\right)^{2}-r(0) B\left(k_{n}\right)\right\} \text { dan } \\
B\left(k_{n}\right)= & \frac{1-e^{-(0.4568) k_{n}}}{0.4568} .
\end{aligned}
$$

Berdasarkan persamaan (25), dihitung nilai tunai anuitas asuransi jiwa endowment suku bunga Vasicek dengan simulasi Monte Carlo untuk pihak tertanggung berusia 30, 35, 40, 45, 50, 55 dan 60 tahun.

Hasil perhitungan nilai tunai anuitas asuransi jiwa endowment suku bunga Vasicek dengan simulasi Monte Carlo dapat dilihat pada Tabel 5.

Tabel 5. Nilai Tunai Anuitas dengan Simulasi Monte Carlo.

\begin{tabular}{|c|c|}
\hline Usia (tahun) & Nilai Tunai Anuitas \\
\hline 30 & 11.7620690 \\
\hline 35 & 11.6437107 \\
\hline 40 & 11.4542098 \\
\hline 45 & 11.1691822 \\
\hline 50 & 10.7461353 \\
\hline 55 & 10.1504364 \\
\hline 60 & 9.3706000 \\
\hline
\end{tabular}

Berdasarkan Tabel 5 dapat dilihat bahwa semakin tinggi usia pihak tertanggung yang mengikuti asuransi, maka akan menghasilkan nilai tunai anuitas yang semakin kecil.

Nilai premi asuransi jiwa endowment suku bunga Vasicek dengan simulasi Monte Carlo dapat ditentukan berdasarkan persamaan (10) dengan nilai tunai manfaat dan nilai tunai anuitas asuransi jiwa endowment suku bunga Vasicek menggunakan simulasi Monte Carlo secara berturut-turut dapat dilihat pada Tabel 4 dan Tabel 5. Hasil perhitungan premi asuransi jiwa endowment suku bunga Vasicek dengan simulasi Monte Carlo dengan uang pertanggungan sebesar Rp. 1,- dapat dilihat pada Tabel 6.
Monte Carlo juga dihitung dengan simulasi sebanyak 5000 dan dirumuskan sebagai:

Tabel 6. Nilai Premi dengan Simulasi Monte Carlo.

\begin{tabular}{|c|c|}
\hline Usia (tahun) & Nilai Premi \\
\hline 30 & 0.0110306 \\
\hline 35 & 0.0118124 \\
\hline 40 & 0.0130945 \\
\hline 45 & 0.0151205 \\
\hline 50 & 0.0182935 \\
\hline 55 & 0.0232433 \\
\hline 60 & 0.0306735 \\
\hline
\end{tabular}

Tabel 6 menunjukkan bahwa nilai premi yang harus dibayarkan pihak tertanggung berusia 35 tahun dengan uang pertanggungan Rp. 100.000.00,- adalah sebesar Rp. 1.181.240,-.

Nilai kerugian dan keuntungan yang dialami perusahaan asuransi dapat ditentukan berdasarkan persamaan (18). Apabila $L_{O}$ bernilai negatif berarti $A_{M C}<P_{M C} . \ddot{a}_{M C}$, hal ini berarti perusahaan asuransi mengalami keuntungan sedangkan apabila $L_{O}$ bernilai positif berarti $A_{M C}>P_{M C} . \ddot{a}_{M C}, \quad$ perusahaan asuransi mengalami kerugian.

Selanjutnya dari nilai $L_{O}$ yang diperoleh, dicari simpangan baku $(s l)$ dan nilai harapan $(\bar{l})$ untuk menentukan kisaran kerugian dan keuntungan premi dengan selang kepercayaan 95\%. Kisaran kerugian dan keuntungan perusahaan asuransi dengan selang kepercayaan $95 \%$ dapat ditentukan berdasarkan persamaan (19). Hasil perhitungannya dapat dilihat pada Tabel 7.

Tabel 7. Kisaran Kerugian dan Keuntungan Perusahaan Asuransi dengan Selang Kepercayaan 95\%

\begin{tabular}{|c|c|}
\hline $\begin{array}{c}\text { Usia } \\
\text { (tahun) }\end{array}$ & Kisaran Kerugian dan Keuntungan \\
\hline 30 & $(-0.0021193,0.0021193)$ \\
\hline 35 & $(-0.0023691,0.0023691)$ \\
\hline 40 & $(-0.0029319,0.0029310)$ \\
\hline 45 & $(-0.0038764,0.0038764)$ \\
\hline 50 & $(-0.0047654,0.0047654)$ \\
\hline 55 & $(-0.0058818,0.0058818)$ \\
\hline 60 & $(-0.0074885,0.0074885)$ \\
\hline
\end{tabular}


Berdasarkan Tabel 7 dapat dilihat bahwa dengan selang kepercayaan sebesar 95\%, kerugian maksimum dan keuntungan maksimum yang dialami perusahaan asuransi untuk pihak tertanggung berusia 35 tahun dengan harga premi sebesar Rp. 1.181.240,- adalah Rp. 236.910,-. Selain itu dari Tabel 7 dapat dilihat bahwa kisaran kerugian dan keuntungan yang dialami perusahaan asuransi akan semakin besar seiring dengan bertambahnya usia pihak tertanggung yang mengikuti asuransi.

Berdasarkan Tabel 3 dan Tabel 6, berikut diberikan perbandingan hasil perhitungan premi asuransi jiwa endowment suku bunga Vasicek tanpa dan dengan simulasi Monte Carlo menggunakan distribusi Gompertz yang dapat dilihat pada Tabel 8.

Tabel 8. Perbandingan Hasil Perhitungan Premi dengan dan tanpa Simulasi Monte Carlo

\begin{tabular}{|c|c|c|}
\hline $\begin{array}{c}\text { Usia } \\
\text { (tahun) }\end{array}$ & $\begin{array}{c}\text { Tanpa Simulasi } \\
\text { Monte Carlo }\end{array}$ & $\begin{array}{c}\text { Dengan Simulasi } \\
\text { Monte Carlo }\end{array}$ \\
\hline 30 & 0.0110092 & 0.0110306 \\
\hline 35 & 0.0117998 & 0.0118124 \\
\hline 40 & 0.0130714 & 0.0130945 \\
\hline 45 & 0.0150939 & 0.0151205 \\
\hline 50 & 0.0182776 & 0.0182935 \\
\hline 55 & 0.0232090 & 0.0232433 \\
\hline 60 & 0.0306743 & 0.0306735 \\
\hline
\end{tabular}

Tabel 8 menunjukkan bahwa nilai premi asuransi jiwa endowment yang dihitung menggunakan simulasi Monte Carlo memberikan hasil yang tidak jauh berbeda dibandingkan nilai premi yang dihitung menggunakan metode numerik (tanpa simulasi Monte Carlo) dengan tingkat ketelitian tiga angka di belakang koma.

\section{KESIMPULAN DAN SARAN}

Hasil perhitungan premi asuransi jiwa endowment suku bunga Vasicek tanpa menggunakan simulasi Monte Carlo menghasilkan nilai premi yang tidak jauh berbeda dengan nilai premi yang dihitung menggunakan simulasi Monte Carlo dengan tingkat ketelitian tiga angka dibelakang koma. Namum, perhitungan premi asuransi menggunakan metode numerik (tanpa simulasi Monte Carlo) tidak dapat dicari kisaran keuntungan atau kerugian yang dialami perusahaan asuransi dengan selang kepercayaan tertentu, sedangkan perhitungan premi asuransi menggunakan simulasi Monte Carlo dapat dicari kisaran kerugian atau keuntungan bagi perusahaan asuransi dengan selang kepercayaan tertentu.

\section{DAFTAR PUSTAKA}

Biro Pusat Aktuaria (Independent and Trusted). 2012. Tabel Mortalita Taspen 2012. Jakarta: PT.Taspen. https://ml.scribd.com/doc/21195675 2/TMT2012. Diakses 19 Juni 2016.

Dickson, D. C. M., Hardy, M. R and Waters, H. R. 2013. Actuarial Mathematic for Life Contingent Risks. United States of America: Cambridge University Press.

http://bookzz.org/md5/C4ADC30B53F17D 6B9B989D728A56DB11.

Diakses 20 Januari

Futami, T. 1993. Matematika Asuransi Jiwa Bagian I. Tokyo: Oriental Life Insurance Cultural Development Centre.

Korn, R., Korn, E and Kroisandt, G. 2010. Monte Carlo Methods and Models in Finance and Insurance. United States of America: Taylor and Francis Group, LLC. http://golibgen.io/view.php?id=1153876. Diakses 11 Januari 2016.

Sanjaya, K. D. 2011. Perhitungan Nilai-Nilai Aktuaria Dengan Asumsi Tingkat Suku Bunga Berubah Secara Stokastik. Jurnal Mat Stat Vol.11 No.2, $149-162$. http://eprints.binus.ac.id/13701/. Diakses 14 November 2015. Pukul 14.18.

Sembiring, R. 1986. Buku Materi Pokok Asuransi I Modul 1-5. Jakarta: Karunika. 
Soffan, Raden Muhamad. 2011. Perhitungan

Premi Asuransi Jiwa Berjangka Menggunakan Model Stokastik Tingkat Suku Bunga. Jurnal BIAStatistika Vol.5 No.1, 1-10.

Zetyun, S. 2007. A Comparative Study of the Vasicek and the CIR Model of the Short Rate. Germany: Fraunhofer-Institut fur Techno-und Wirtschaftsmathematik. 